\title{
Research on Innovation and Entrepreneurship Talent Training Model for Application-Oriented University under Perspective of Collaborative Innovation
}

\author{
Zhou Jixiang and Zhou Yuezhou
}

\begin{abstract}
Under the new situation of mass entrepreneurship and innovation, actively constructing new model and new mechanism of collaborative innovation and conducting innovation and entrepreneurship education for universities are important means and primary mission of model innovation of applied talent training. Synthesizing all the resources from government, enterprises and universities can provide new perspective for innovation and entrepreneurship talent training, and is also an effective way for training innovation and entrepreneurship talents under the new normal. This paper summarizes the dilemma and issues of conducting innovation and entrepreneurship education for application-oriented university, and analyzes the influence factors of undergraduate innovation and entrepreneurship education. Then, it establishes a collaborative education model connecting government, enterprises and education based on triple helix theory, and proposes the implement approaches of innovation and entrepreneurship talent training model for application-oriented university, such as the cultural development of innovation and entrepreneurship, constructing the whole process of education system and building multi-layer practical educational platform. All these approaches can provide intellectual support and talent guarantee for the transformation development of local economy structure.
\end{abstract}

Index Terms-Applied talent training, collaborative innovation, innovation and entrepreneurship, implement approach, triple helix theory.

\section{INTRODUCTION}

The Outline of the National Medium and Long-Term Educative Reform and Development Plan (2010-2020) clearly states "establishing the new mechanism for jointly cultivating talents between universities and research institutes, industries and enterprises" [1]. Facing the trend changes and characteristics under the new normal of economic development, colleges should actively respond to the country's call of duty, deepen the reform of innovation and entrepreneurship education, actively construct new models and mechanisms for collaborative innovation, and lead and support social innovation and development. The lack of resources in local colleges and universities is an important

Manuscript received February 29, 2019; revised May 28, 2019. This paper is one of the periodic achievements of Higher Education Teaching Research and Reform Project of Guangdong Province, Research and Practice of Classroom Teaching Quality Monitoring System in Independent Colleges (No.: JY180302).

Zhou Jixiang is with the Guangzhou College of South China University of Technology, Guangzhou 510800, China (e-mail: jixiang@scut.edu.cn).

Zhou Yuezhou is with the Northeastern University, Shenyang 110004, China (e-mail: 1739174949@qq.com). factor restricting the cultivation of applied talents in colleges and universities. Therefore, colleges and universities should combine innovation and entrepreneurship education with the needs of regional economic development, and effectively collect and integrate high-quality innovative resources inside and outside the school, to form an innovative and entrepreneurial education ecosystem with the joint participation and benign interaction of university, government, and enterprises. Carrying out innovation and entrepreneurship education based on collaborative innovation is an important means to improve the quality of applied talents, thus providing intellectual support and talent guarantee for the transformation and development of local economic structure.

\section{THE DILEMMA OF INNOVATION AND ENTREPRENEURSHIP EDUCATION IN APPLIED UNDERGRADUATE COLLEGES AND} UNIVERSITIES

\section{A. Lack of Adequate Funds and Qualified Teachers}

The implementation of innovation and entrepreneurship education in colleges and universities requires the support of funds and human resources as a guarantee. However, compared with first-class colleges and universities, it is difficult for applied undergraduate colleges to obtain financial support and social resources. The serious shortage of teaching software and hardware resources makes it difficult to implement innovation and entrepreneurship education in the whole process of talent cultivation, which is the bottleneck restricting the teaching of applied colleges and universities. There is no specific implementation agency and special funds for innovation and entrepreneurship education. Many colleges and universities only add this content in Students' Affair Division, which leads to the inappropriate management of innovation and entrepreneurship education and insufficient or even misappropriated funds for innovation and entrepreneurship. Most of the teachers in applied undergraduate colleges engage in the teaching directly after graduation, thus lacking working experience in enterprises and self-employment experience, as well as system knowledge such as enterprise management, marketing, financial management, risk control and legal knowledge. Teaching concepts and teaching methods are backward. Traditional teaching and "cramming" teaching methods are generally used while case teaching, practical teaching and project teaching are less applied. These problems severely limit the development of students' innovative thinking and restrict the improvement of students' innovative ability. 


\section{B. Difficult Implementation of Effective Cooperation with the Society}

In the era of market economy, colleges and universities aim to improve the quality of personnel training, and enterprises aim to improve economic efficiency. The objectives of the two are consistent in some respects, but the differences are very obvious, which makes it difficult for colleges and universities to obtain quality enterprises as the resources of collaborative innovation and cooperative education. Innovation and entrepreneurship education cultivates college students' ability to solve practical problems with innovative thinking, skills and actions through guiding them to discover practical problems. At present, most enterprises still consider their own profits in the process of cooperation with universities. They hope that school-enterprise cooperation can solve technical problems, reduce research and development costs, and improve economic efficiency, but are not active in providing human and material resources and funds or deeply participating in the whole process of talent training in colleges and universities, which leads to a lack of common education atmosphere and long-term mechanisms in the entire society.

\section{Disconnection between Talent Training Model and the Society}

College education administrators lack a deep understanding on the core connotation of "innovation and entrepreneurship". Innovation and entrepreneurship education presents an one-way chain from school to employment, rather than a two-way chain between school and market demand. Innovation and entrepreneurship education lacks a systematic and standardized training model. Some schools pay too much attention to the integrity of theory and cultivation of professional knowledge, ignoring the cultivation of students' practical ability and innovative and entrepreneurial ability, so that the cultivated talents cannot meet the needs of social development in terms of knowledge structure, capacity structure and quality structure, and the quality of graduates cannot meet the production needs of enterprises. Thus, it is difficult for students to find satisfactory jobs after graduation. Some colleges and universities have not incorporated innovation and entrepreneurship education into the school's normalized teaching and training plan, only staying at the level of employment guidance and entrepreneurial competition activities, but ignoring the cultivation of talents' comprehensive ability and the improvement of professional quality. Due to lack of implementation capability and professional responsibility, students trained in this way frequently quit and change projects in the process of employment or entrepreneurship.

\section{CONSTRUCTING A COOPERATIVE EdUCATION MODEL OF GOVERNMENT, INDUSTRY AND SCHOOLS BASED ON THE THEORY OF TRIPLE HELIX}

In the 1950s, the American geneticist Richard Leventin proposed the concept of "triple helix", using three cross-helix rising lines to explain the "dialectical relationship" between genes, organisms and the environment. In the 1990s, with the advent of the era of knowledge economy, colleges and universities have become the main part of national technological innovation. American scholar Henry Etzkowitz and Netherlandish scholar Lutter Leydesdorff applied the theory of "triple helix" in the field of biology into the field of sociology, and constructed the model of "university-industry-government relationship" [2]. The theory of "triple helix" advocates that "university-industrygovernment" should realize resource sharing and mutual intersection and integration in the process of knowledge production, to jointly promote knowledge production, application, industrialization and upgrading, and improve the efficiency of collaborative innovation [2]. At present, the theory of "triple helix" has become one of the mainstream theories of innovation and entrepreneurship research [3].

In the process of breaking the respective barriers of the "university-industry-government" and integrating the innovative resources of the main parts of triple helix, each of the three main parts performs its own functions and advantages, and interaction and integration are strengthened, to realize the mutual transformation and penetration of the roles, thus promoting the formation of a benign spiral interaction between subjects. A collaborative education model of government, industry and university based on the theory of triple helix is constructed (see Fig. 1). In the personnel training model of innovation and entrepreneurship, the government is in a dominant position, giving full play to the functions of guidance, supervision and evaluation, creating an environment, improving the innovation and entrepreneurship management mechanism, promoting the rational flow and utilization of knowledge, capital, talents, information and technology and providing system and policy guarantee to support college students' innovation and entrepreneurship. The government should build a multi-channel financial support system including government specialization, industry participation, social fundraising and venture capital participation through its own advantages. The government should guide and support the school-enterprise cooperation to jointly build a joint laboratory and college student practice base, and build a platform for information sharing, cooperation and exchange for college students' innovation and entrepreneurship based on the college science park and innovation incubation base. The industry plays a driving role in the process of innovation and entrepreneurship education, and is expected to transmit the latest market information and technical resources to universities, making the content of innovation and entrepreneurship education in colleges and universities can meet the market demand. The industry should use its own advantages to set up innovation and entrepreneurship compensation fund, send senior engineers with entrepreneurial practical experience as part-time instructors, establish a professional practice platform for college students, build a platform for technological achievements transformation, jointly build innovative and entrepreneurial parks, incubators and laboratories with colleges and universities, and provide investment in human resources, material resources and financial resources for colleges and universities. Colleges and universities are the core of the innovation and entrepreneurship ecosystem, and the key to knowledge innovation, production and transformation. Colleges and 
universities should establish an incentive mechanism for innovation and entrepreneurship, strengthen the construction of innovative and entrepreneurial faculty, and increase capital investment to promote the transformation of scientific research results. Colleges and universities should establish a sound innovation and entrepreneurship curriculum system and a practical teaching system, expand financing channels, actively carry out project cooperation with industries and build practical platforms, to improve the practical teaching system [4].

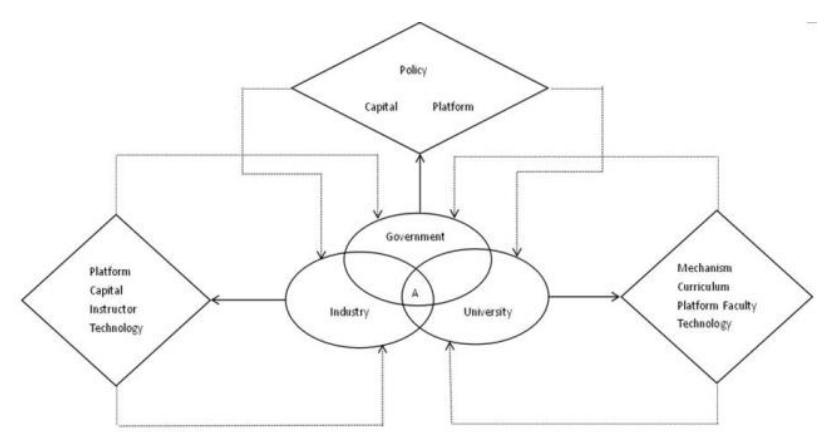

Fig. 1. Cooperative education model of government, industry and Schools of "Triple Helix".

\section{IMPLEMENTATION PATHS OF THE TRAINING MODE OF INNOVATIVE AND ENTREPRENEURIAL TALENTS IN APPLIED UNDERGRADUATE UNIVERSITIES}

As an application-oriented university, Guangzhou College of South China University of Technology (GCU for short) has conducted the mode reform of innovation and entrepreneurship talent training since 2010. Through creating the atmosphere of innovation and entrepreneurship, building the educational system of entire process innovation and entrepreneurship, setting up multi-layer practical educational platform along with the intramural and out-college base, and cultivating the synthetical teach staff, this school has obtained a series of achievements in innovation and entrepreneurship education. In 2017, the school was successfully awarded the "Model School of Guangdong Provincial College Student Innovation and Entrepreneurship Education.

\section{A. Creating an Atmosphere of Innovation and Guiding the Development of Innovative and Entrepreneurial Culture}

Active innovative and entrepreneurial culture is the "soft environment" in the application-oriented talent cultivation ecosystem with the in-depth integration of "industry, professionalism and entrepreneurship" [5], which is an important driving force for promoting regional economic development. In the integration network "industry, professionalism and entrepreneurship", the government needs to provide environmental support, such as legal and regulatory protection, industrial policy guidance, capital security, fiscal and tax incentives, information sharing, entrepreneurial culture, etc., thus promoting the virtuous circle of the elements in the innovation and entrepreneurship ecosystem. The government should set up various innovative and entrepreneurial organizations and service agencies linking industries and universities, to promote the industry's support and services of human resources, material resources, capital and technology for innovation and entrepreneurship education in colleges and universities. The Internet, WeChat public number and other media means are applied to propagate the typical model deeds of college students' innovation and entrepreneurship, and then to create a good social innovative and entrepreneurial atmosphere subtly, and enhance the society's recognition and attention to college students' innovation and entrepreneurship. Colleges and universities should vigorously advocate college students to pursue truth and devote to science, and strive to create an innovative culture that encourages innovation and accepts failure. Recent years, through the innovation and entrepreneurship general education curriculum system, the perfect innovation and entrepreneurship management system, the cultivation and transformation system of teachers and students' innovation and entrepreneurship achievements, and the campus media's propaganda service system for innovation and entrepreneurship, a new normal of applied talent cultivation is built in Guangzhou College of South China University of Technology.

\section{B. Adhering to Systematic Thinking and Building the Whole Process of Innovation and Entrepreneurship Education System}

During the innovation and entrepreneurship education, it's necessary to promote the triple helix subject linkage among university, government and enterprise, and form the cooperative education mechanism with resource complementarity, risk sharing and benefit sharing. The innovation and entrepreneurship education is an important part of talent training. Thus, it's important to keep the deep combination of in and outside class, and realize the innovation and entrepreneurship education through the whole process of talent training. Guangzhou College of South China University of Technology established the educational steering committee composed of government representative, industry experts and other representatives, and tried to optimize the top-level design. Also, this school jointly formulated and revised the talent training program, and jointly carried out the quality monitoring of different training segments. Moreover, the school builds a " 3 platforms +6 modules" curriculum system. The three platforms refer to the quality education platform, the professional education platform and the practical teaching platform. The six modules refer to the public elective courses, public basic courses, subject basic courses, professional compulsory courses, professional elective courses and personal development courses. In the quality education platform, the school can set up innovative and entrepreneurial general education courses for all students, to teach innovative ideas, entrepreneurial theories, marketing, financial management, investment and other knowledge and to cultivate students' awareness and ability of innovation and entrepreneurship. Infiltrate the concepts of innovation, creativity and creation in professional education, integrate teachers' scientific research achievements, disciplines' frontier theories and knowledge, and enterprises' innovation achievements into the teaching content as well as all aspects of teaching, introduce new knowledge, skills and processes of industries and enterprises, develop comprehensive courses, problem-oriented courses, workflow-based courses and cross-disciplinary research courses, and improve curriculum 
interest and academic challenges throughout the teaching process. Build a second class of "project + competition + entrepreneurship". Through innovative and entrepreneurial training programs, innovative and entrepreneurial competitions and incubator establishment, students' ability of invention creation and entrepreneurial practice would be enhanced, to provide effective channels and conditions for innovative and entrepreneurial implementation.

\section{Gathering High-quality Educational Resources and Building Multi-level Practical Education Platform}

Innovation and entrepreneurship education is a brand-new talent training mechanism. Colleges and universities should integrate the advantages of disciplines, talents, platforms and other resources [6], and jointly build a diversified and multi-level practical education platform meeting the needs of the market with enterprises, to promote the development of innovation and entrepreneurship education. Guided by mutual benefit and win-win result, Guangzhou College of South China University of Technology should actively introduce enterprises with strong strength and high social credibility, adhere to the concept of "co-construction, co-management, sharing, and win-win", and promote a new cooperative model of school-enterprise joint training base. Two industrialized colleges constructed and managed by multiple subjects, such as ZTE Engineering College and Intelligent Manufacturing Industry College, one national- level college student practice base, five experimental demonstration centers in Guangdong Province, four provincial-level practical bases outside school, one provincial-level collaborative education center, and six school-level collaborative innovation centers are established, which provide strong support for cultivating high-quality applied talents. The school can utilize the complementarity of disciplines, talent advantage and enterprise technology resources to promote the development of collaborative education, and set vehicle engineering special classes, Youni talent classes, mechanical engineering innovation classes and so on, to cultivate professional talents for enterprises. According to the requirements of engineering education's professional certification standards, the school can combine the needs of industries and enterprises for the knowledge structure, engineering application and innovation capabilities of applied talents, to jointly develop enterprise practice quality standards with enterprises and to ensure the quality of enterprise practice. The knowledge and capabilities of the engineering field are decomposed and integrated, and a four-level practical teaching system of professional technical ability, comprehensive application ability, engineering practice ability and professional innovation ability is constructed through the integration of school and enterprise (see Fig. 2).

\section{Integrating and Coordinating, and Cultivating a Faculty of Full-Time and Part-Time Teachers}

Teachers of innovation and entrepreneurship must not only have a profound theoretical knowledge, but also have rich practical experience and strong entrepreneurial practice ability, which puts higher requirements on the construction of the teaching staff. The school should strengthen the engineering background of teachers, innovate the employment mechanism, and take the diversified way combining full time and part time, internal and external [7], and industry, university and research, to form "double-type" and "innovative and entrepreneurial" faculty with distinctive characteristics and reasonable structure of full-time and part-time teachers. First, GCU can formulate Measures for the Implementation of "Innovation and Entrepreneurship" Reform and Measures for the Recognition and Management of Teachers with "Dual Professions", define that "innovative and entrepreneurial" education is the responsibility of all teachers, encourage teachers to participate in the "innovative and entrepreneurial" practice in social industries, send young teachers to work part-time in the enterprises, and take their practical experience and achievements in the enterprises as an important condition for annual assessment, selection of key positions, and promotion of professional titles, so as to improve the effectiveness of "double-type" and "innovative and entrepreneurial" teachers training. The university should improve the academic qualification improvement, training, studying and visiting mechanism of full-time teachers, optimize the structure of teachers, and improve the quality of teachers. Secondly, the school can formulate Administrative Measures on Appointing Visiting Professors, Consultant Professors, Part-time Professors and Various Part-time Professional and Technical Personnel, actively recruit outstanding talents such as well-known scientists, and successful entrepreneurs as full-time or part-time teachers, establish a professional teaching and steering committee with local industries and employing units' participation, focus on the in-depth integration of "industry, professionalism and entrepreneurship", and participate in the whole process of discipline construction, talent development plan formulation, curriculum setting, textbook writing, practical platform construction and other professional construction and teaching activities. Through jointly building innovation and entrepreneurial courses, mutual recognition of credit and achievement sharing, different universities can realize the sharing of high-quality resources [8].

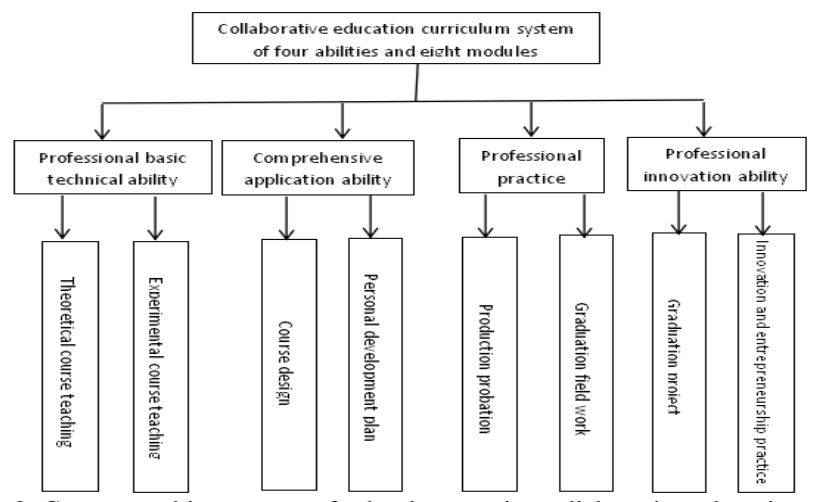

Fig. 2. Course teaching system of school-enterprise collaborative education platform.

\section{E. Building Entrepreneurial Platforms to Help Entrepreneurial Practice}

Colleges and universities should take the initiative to meet the needs of regional economic development, open up the financing and entrepreneurship channels inside and outside the school, build a diversified and multi-level training 
practice platform of innovative and entrepreneurial talents, and promote the integration of industry, profession and entrepreneurship. In recent years, the school has established student entrepreneurship parks and "innovative and entrepreneurial" education colleges, as well as start-up project incubation zones, innovation laboratories, multi-functional seminar halls, etc., and purchased various professional teaching software such as entrepreneurial pioneers' practical platform software, human resources management sand table and so on. Students participate in the university student's innovation and entrepreneurship programs, SYB entrepreneurship training course, interdisciplinary training, entrepreneurship competition and other activities. In the past three years, our school has made great achievements in various "innovative and entrepreneurial" activities such as the "Challenge Cup" College Student Entrepreneurial Plan Competition and the ICAN Internet of Things Innovation and Entrepreneurship Competition. A total of 48 teams and 203 students have won awards. The school has opened channels for financing and entrepreneurship inside and outside the school, introduced venture capital institutions, social fundraising and other funds to support the development of innovative technologies and the entrepreneurship for teachers and students, and introduced the "innovative and entrepreneurial" projects to the off-campus incubation platform. 34 registered enterprises have been realized, and student financing has reached 16 million yuan.

\section{CONCLUSION}

Although the government-enterprises-education cooperative education mode based on triple helix theory provides new perspective for innovation and entrepreneurship talent cultivation in the universities, the exploration of cooperative education is still not thoroughgoing. In practice, it is necessary to further realize new breakthroughs in terms of two aspects. One is to achieve the synergy among the theory, internship and practice of innovation and entrepreneurship, and explore the establishment of a crossed and syncretic curriculum system. And another is to attempt to effectively connect the innovation and entrepreneurship, actively promote the innovation-oriented entrepreneurship, and in turn promote the development of innovation through the entrepreneurship.

\section{REFERENCES}

[1] Ministry of Education. The Outline of the National Medium and Long-Term Educative Reform and Development Plan (2010-2020) [Online].

Available: http://old.moe.gov.cn/publicfiles/business/htmlfiles/moe/info_list/201 407/xxgk_171904.html

[2] Y. L. Chen and D. L. Li, "The practice and model construction of collaborative education of government, industry and school from the perspective of Triple Helix theory," Heilongjiang Higher Education Exploration, no. 8, pp. 87-90, 2018.

[3] M. F. Li, J. Wang, Y. B. Wang, M. T. Wang, and Y. X. Zhao, "The triple helix system of university-industry- government and regional entrepreneurship: Relevance and regional differences," Studies in Science of Science, vol. 34, no. 8, pp. 1211-1222, Sep. 2016.

[4] Z. G. Gao, "Research on the mechanism of the synergy of the three helix theory: a case study of science and technology park of Chinese universities," Shanghai Management Science, vol. 37, no. 3, pp 102-105, Aug. 2015

[5] J. J. Lin, Y. C. Shi, and P. Li, "Constructing application-oriented talent cultivation culture integrating "industry, profession and entrepreneurship"," China Higher Education, no. 21, pp. 43-45, 2017

[6] Y. J. Wang, "Promoting the model reform of talent training with seizing the opportunity of building collaborative innovation mechanism," China Higher Education, no. 21, pp. 33-35, May 2012.

[7] X. K. Zhang, "Concept innovation and implementation path for talent training in application-oriented university," Jiangsu Higher Education, no. 5, pp. 38-41, June 2017.

[8] N. Ma, L. H. Zeng, and Y. Liu, "Study on the entrepreneurship education model of applied undergraduate colleges and universities based on cooperative innovation," Research in Higher Education of Engineering, no. 4, pp. 146-150, 2017.

Copyright $(2019$ by the authors. This is an open access article distributed under the Creative Commons Attribution License which permits unrestricted use, distribution, and reproduction in any medium, provided the original work is properly cited (CC BY 4.0).

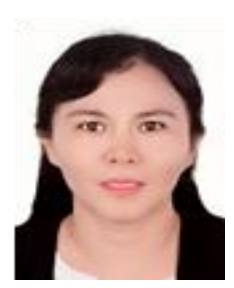

Zhou Jixiang was born in Huanggang, Hubei, in 1975. She is associate researcher. Her research interests are in higher education management.

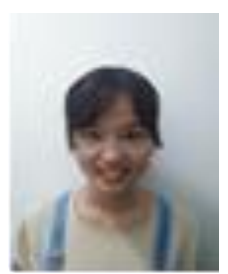

Zhou Yuezhou was born in Guangzhou, Guangdong, in 1998. She is engaging in research on computer technology. 